\title{
PRODUCTION OF STRUCTURED LIPIDS FROM HAZELNUT OIL WITH CONJUGATED LINOLEIC ACID BY LIPASE-CATALYZED ESTERIFICATION: OPTIMIZATION BY RESPONSE SURFACE METHODOLOGY
}

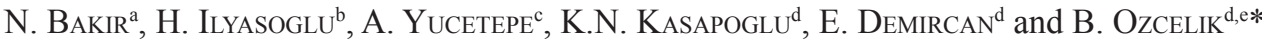 \\ ${ }^{a}$ Republic of Turkey Ministry of Food, Agriculture and Livestock, Istanbul Directorate of Provincial Food \\ Agriculture and Livestock, Istanbul. Turkey \\ ${ }^{b}$ Department of Nutrition and Dietetics, Health School, Gumushane University, TR-29100, Gumushane. Turkey \\ ${ }^{\mathrm{c}}$ Department of Food Engineering, Faculty of Engineering, Aksaray University, TR-68100, Aksaray. Turkey \\ ${ }^{\mathrm{d}}$ Department of Food Engineering, Faculty of Chemical and Metallurgical Engineering, Istanbul Technical \\ University, Maslak, TR-34469, Istanbul. Turkey \\ e BIOACTIVE Research \& Innovation Food Manufac. Indust. Trade Ltd., Katar Street, Teknokent ARI-3, B110, \\ Sarıyer, 34467, Istanbul. Turkey
}

(Received: 16 October 2016; accepted: 11 July 2017)

The aim of this study was to synthesize structured lipid from hazelnut oil with conjugated linoleic acid (CLA) by lipase-catalyzed esterification reaction. The incorporation of CLA into hazelnut oil was optimized by response surface methodology (RSM). Substrate molar ratio, time, and temperature were independent variables chosen for optimization of the reaction. Substrate molar ratio was the most significant variable on the incorporation of conjugated linoleic acid. Good quadratic model was achieved by multiple regression analysis and backward elimination. Optimal incorporation conditions were determined as follows: reaction temperature, $59{ }^{\circ} \mathrm{C}$; time, 6 hours; substrate molar ratio, 4 . Under these optimum conditions, a maximum incorporation ratio of CLA into hazelnut oil of $49.42 \%$ was achieved.

Keywords: conjugated linoleic acid, hazelnut oil, response surface methodology, structured lipid.

Conjugated linoleic acids (CLAs) are a group of positional and geometric isomers of linoleic acid with conjugated double bonds at 7,9-, 8,10-, 9,11-, 10,12-, or 11,13- of the carbon chain in either the cis- or trans-configuration. CLA, a product of bacterial biohydrogenation of linoleic acid, is naturally found in animal products such as beef, lamb, and dairy products from ruminant animals (LEÃo et al., 2015; Aloud et al., 2016; FernandeZ-Avila et al., 2016). CLA has been reported to have several beneficial health-related effects (SALAMON et al., 2015). Anticancerogenic (Kelley et al., 2007), antiatherogenic (McLeOd et al., 2004), immuno-modulating antidiabetic (RYDER et al., 2001), and antiinflammatory (NASRABADI et al., 2016) properties of CLA have been determined by using animal models and cell cultures.

Humans obtain CLA from only dietary sources, since the human body is unable to synthesize CLA. In recent years, the replacement of animal lipids by plant lipids has resulted in decrease in the consumption of dietary CLA. Structured lipids (SL) can be obtained via two ways: chemical reaction and enzymatic reaction. Enzymatic modification is widely preferred because it is possible to produce regiospecifically modified or restructured triacylglycerol by using lipase (CAN \& OzCELIK, 2004; KAHVECI et al., 2009). Synthesizing of structured lipids (SL) may be alternative way to provide CLA for nutritive and therapeutic requirements (LEE et al., 2004; Alim et al., 2008). Safflower oil (LEE et al., 2004), rice brain

\footnotetext{
* To whom correspondence should be addressed.

Phone: +90 212285 3448; fax: +90 212285 2925, e-mail: ozcelik@itu.edu.tr
}

0139-3006 @ 2018 Akadémiai Kiadó, Budapest 
oil (Alim et al., 2008), olive oil (LeE et al., 2006), corn oil (Vu et al., 2007), and soybean oil (Hernández-Martín \& Otero, 2008) have been used to produce SLs enriched with CLA. Hazelnut oil is known to have several health benefits. It may be possible to produce a dietary lipid from hazelnut oil and CLA by lipase-catalyzed esterification reaction.

The aim of this study was to produce SL from hazelnut oil and CLA by means of enzymatic interesterification. To our knowledge, there is no available study on the production of SL from hazelnut oil and CLA. RSM was used to determine the effect of three variables (substrate molar ratio, reaction temperature and time) on the incorporation of CLA into hazelnut oil.

\section{Materials and methods}

\subsection{Materials}

Refined hazelnut oil was acquired from a supermarket (Istanbul, Turkey). Lipozyme ${ }^{\circledR}$ TL IM, immobilized 1,3 specific lipase, was kindly supplied by Novo Nordisk A/S (Bagsvaerd, Denmark/Turkey branch). CLA standard and fatty acid standard mixture were obtained from Supelco (Bellefonte, PA). Organic solvents were obtained from J.T. Baker Chemical Co. (Phillipsburg, NJ) and Merck (Darmstadt, Germany).

\subsection{Method}

1.2.1. Experimental design. The independent variables were the following: substrate molar ratio ( $\mathrm{Sr}, \mathrm{CLA} /$ hazelnut oil), $\left(1.3-4.6 \mathrm{~mol} \mathrm{~mol}^{-1}\right)$; temperature $\left(\mathrm{T},{ }^{\circ} \mathrm{C}\right),\left(35-65^{\circ} \mathrm{C}\right)$; and time $(\mathrm{t}, \mathrm{h}),(0-30 \mathrm{~h})$. A three-variable, five-level rotatable central composite design (CCD) was used for the RSM studies, and 19 experimental settings were generated with three factors. Experiments were randomly run at all design points. A total of 19 runs with 8 factorial points, 5 center points, and 6 axial points were generated. The regression analyses, response surfaces analysis, and the analysis of variance (ANOVA) were performed using Design Expert 7.1 software (Stat-Ease Inc., MN). The independent variables and the reaction conditions are shown in Table 1.

Table 1. Uncoded and coded levels of the independent variables of the experiments

\begin{tabular}{lccccccc}
\hline Independent variable & Units & Symbol & \multicolumn{5}{c}{ Factor levels } \\
\cline { 4 - 8 } & & & -1.68 & -1 & 0 & 1 & 1.68 \\
\hline Substrate molar ratio & $\mathrm{mol} \mathrm{mol}^{-1}$ & $\mathrm{X}_{1}$ & $1: 1.3$ & $1: 2$ & $1: 3$ & $1: 4$ & $1: 4.6$ \\
Temperature & ${ }^{\circ} \mathrm{C}$ & $\mathrm{X}_{2}$ & 35 & 41 & 50 & 59 & 65 \\
Time & $\mathrm{h}$ & $\mathrm{X}_{3}$ & 0 & 6 & 15 & 24 & 30 \\
\hline
\end{tabular}

1.2.2. Acidolysis. A mixture of CLA and hazelnut oil at various substrate molar ratios $(1: 1.3,1: 2,1: 3,1: 4,1: 4.6)$ was prepared, and $30 \mathrm{ml}$ hexane and Lipozyme TL IM (10\% of total reactants) were added. The reaction mixture was placed in a water bath at $35^{\circ} \mathrm{C}, 41^{\circ} \mathrm{C}$, $50{ }^{\circ} \mathrm{C}, 59^{\circ} \mathrm{C}$, and $65^{\circ} \mathrm{C}$ for $0,6,15,24$, and $30 \mathrm{~h}$.

1.2.3. Extraction of triacylglycerol. To remove free fatty acids, the reaction mixture was combined with $5 \mathrm{ml}$ ethanol and $5 \mathrm{ml}$ hexane and titrated with $0.02 \mathrm{~mol}^{-1}$ sodium hydroxide. After the TAG was extracted into hexane. This process was followed by separating of hexane 
phase from water phase and drying with sodium thiosulphate. Then, the hexane was removed under vacuum in a rotary evaporator.

1.2.4. Determination of fatty acid composition. Fatty acid methyl esters (FAME) analysis was performed by adding $3 \mathrm{ml} \mathrm{HCl}$ in methanol $(6 \mathrm{~g} / 100 \mathrm{ml})$ solution and $50 \mu \mathrm{l}$ internal standard $\left(10 \mathrm{mg} \mathrm{ml}^{-1}\right.$ heptadecanoic acid) to TAGs in an oven at $70-80^{\circ} \mathrm{C}$ for $2 \mathrm{~h}$. Then, FAME were extracted in duplicate with $2 \mathrm{ml}$ of hexane and $1 \mathrm{ml}$ of $\mathrm{KCl}$. For separation of moisture from FAMEs, the extraction products were filtered using a sodium sulphate column and the solvent was reduced to $0.5 \mathrm{ml}$ under nitrogen stream (JeNNINGS and Акон, 1999). Gasliquid chromatography (GLC) was used to analyse the fatty acid composition of substrates and reaction products. Thermoquest Trace GC 2000 was equipped with a J\&W DB-wax (J\&W Scientific, Folsom, CA) column $(30 \mathrm{~m} \times 0.25 \mathrm{~mm}$ id with a film thickness of $0.25 \mu \mathrm{m})$ and a flame ionization detector (FID) operated on split mode with split ratio of 1:50. Temperatures of the injector and detector were $250{ }^{\circ} \mathrm{C}$ and $260{ }^{\circ} \mathrm{C}$, respectively. The initial column temperature was $150^{\circ} \mathrm{C}$ for $3 \mathrm{~min}$, and then programmed to $215^{\circ} \mathrm{C}$ at $10^{\circ} \mathrm{C} \mathrm{min}{ }^{-1}$, held for 10 minutes. Relative contents of FAME as mol\% were calculated by software.

1.2.5. Statistical analysis. The effect of the studied three factors, namely substrate molar ratio, reaction temperature, and time, and their interactions were statistically analysed by ANOVA using Design Expert 7.1 software (Stat-Ease Inc., MN).

\section{Results and discussion}

\subsection{Fatty acid compositions}

Fatty acid composition of substrates obtained by GC are presented in Table 1 and Figures 1 and 2. Moreover, fatty acid compositions of reaction products are shown in Tables 2 and 3. As shown, hazelnut oil was determined to contain oleic acid (82.9\%), linoleic acid (9.8\%),

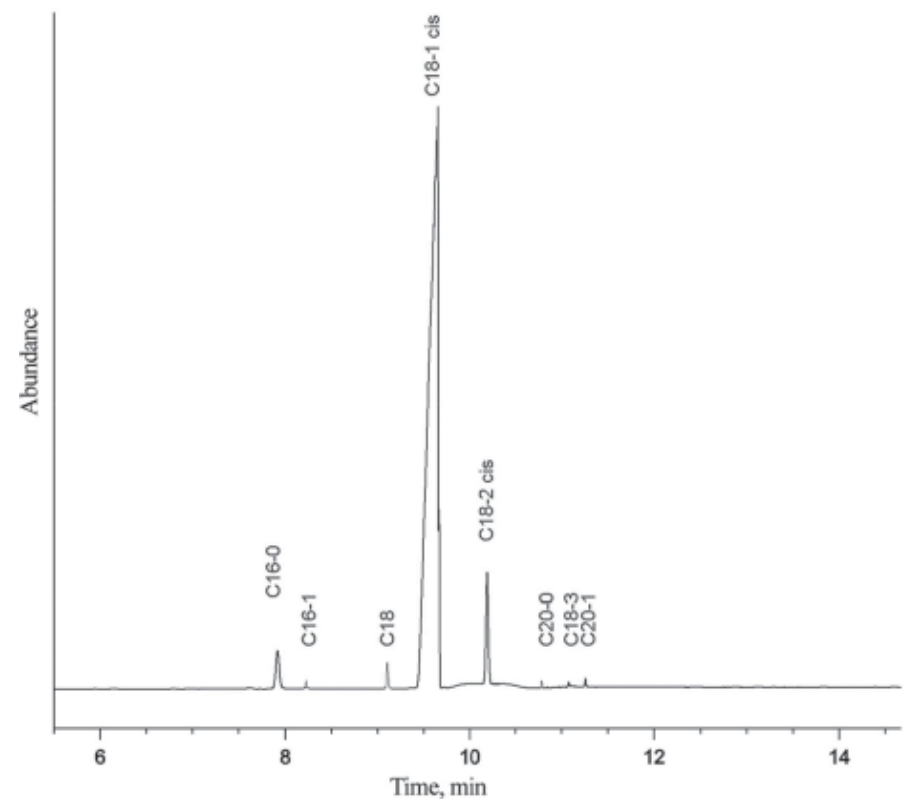

Fig. 1. GC chromatogram of hazelnut oil 
palmitic acid (5.2\%), and stearic acid (2.1\%). CLA standard contained CLA (56.8\%), linoleic acid (31.4\%), palmitic acid (6.8\%), and oleic acid (3.8\%) as main constituents. After acidolysis, the major unsaturated fatty acids were determined as $\mathrm{C} 18: 1$ and $9 \mathrm{c}, 11 \mathrm{t}$ and $10 \mathrm{t}$, $12 \mathrm{c}$ isomers of CLA in reaction products.

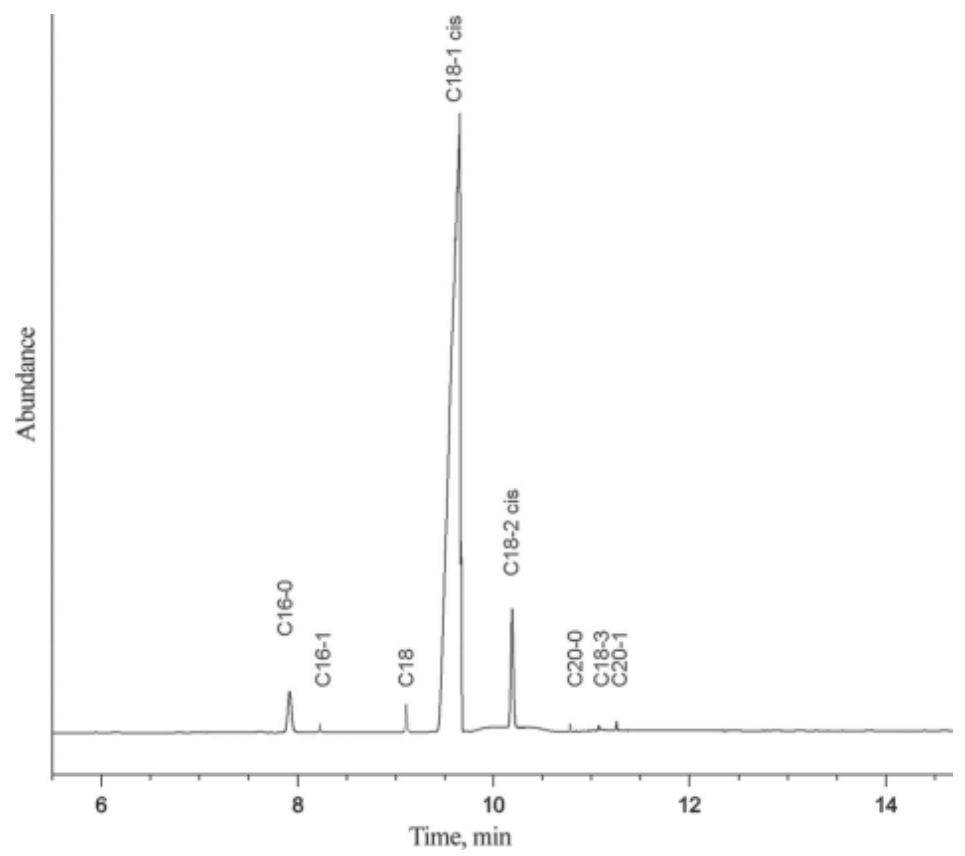

Fig. 2. GC chromatogram of CLA standard

Table 2. Fatty acid composition of hazelnut oil and CLA

\begin{tabular}{lccccccccc}
\hline Sample & \multicolumn{10}{c}{ Fatty acid (\%) } \\
\cline { 2 - 10 } & C16:0 & C16:1 & C18:0 & C18:1 & C18:2 & C18:3 & C20:0 & C20:1 & CLA \\
\hline Hazelnut oil & 5.41 & 0.21 & 2.40 & 82.44 & 9.21 & 0.07 & 0.08 & 0.17 & - \\
CLA & 6.80 & 0.11 & 0.04 & 3.75 & 31.38 & - & 0.53 & 0.36 & 56.76 \\
\hline
\end{tabular}

Table 3. Fatty acid composition of reaction products

\begin{tabular}{lcccccccccc}
\hline Trial No & C16:0 & C16:1 & C18:0 & C18:1 & C18:2 & $9 \mathrm{c}, 11 \mathrm{t}$ & $10 \mathrm{t}, 12 \mathrm{c}$ & 11c,13t & $8 \mathrm{t}, 10 \mathrm{c}$ & $\begin{array}{c}\text { Total } \\
\text { CLA }\end{array}$ \\
\hline 1 & 5.00 & 0.21 & 2.48 & 41.77 & 8.60 & 15.22 & 19.63 & 2.97 & 3.18 & 41.00 \\
2 & 5.88 & - & 2.92 & 58.32 & 8.07 & 2.96 & 3.98 & - & 1.19 & 24.80 \\
3 & 6.41 & - & 3.42 & 34.24 & 8.14 & 17.87 & 22.11 & 3.18 & 4.62 & 47.78 \\
4 & 5.66 & - & 2.91 & 39.87 & 8.45 & 16.13 & 20.70 & 2.77 & 3.51 & 43.11
\end{tabular}


Table 3. continued

\begin{tabular}{lcccccccccc}
\hline Trial No & C16:0 & C16:1 & C18:0 & C18:1 & C18:2 & $9 \mathrm{c}, 11 \mathrm{t}$ & $10 \mathrm{t}, 12 \mathrm{c}$ & $11 \mathrm{c}, 13 \mathrm{t}$ & $8 \mathrm{t}, 10 \mathrm{c}$ & $\begin{array}{c}\text { Total } \\
\text { CLA }\end{array}$ \\
\hline 5 & 7.89 & - & 3.88 & 36.69 & 8.82 & 15.10 & 18.65 & 2.86 & 6.10 & 42.71 \\
6 & 6.25 & - & 2.95 & 36.36 & 9.05 & 16.47 & 20.23 & 3.09 & 5.59 & 45.38 \\
7 & 7.90 & 0.20 & 4.06 & 32.76 & 7.80 & 15.19 & 18.80 & 3.21 & 8.31 & 45.51 \\
8 & 6.66 & - & 2.47 & 41.04 & 7.82 & 14.96 & 18.58 & 2.77 & 5.31 & 41.62 \\
9 & 7.02 & - & 3.69 & 36.77 & 8.05 & 15.85 & 20.52 & 2.94 & 5.16 & 44.47 \\
10 & 5.06 & - & 2.68 & 40.30 & 8.40 & 15.77 & 20.05 & 2.92 & 4.82 & 43.56 \\
11 & 6.04 & - & 3.01 & 46.33 & 8.55 & 13.35 & 16.74 & 2.39 & 3.58 & 36.07 \\
12 & 6.87 & - & 3.53 & 38.84 & 8.24 & 15.53 & 19.75 & 2.79 & 4.45 & 42.52 \\
13 & 6.04 & - & 2.91 & 41.50 & 8.68 & 15.00 & 18.67 & 2.71 & 4.48 & 40.87 \\
14 & 5.74 & - & 2.53 & 47.00 & 8.16 & 13.55 & 17.01 & 2.36 & 3.65 & 36.57 \\
15 & 4.93 & - & 2.14 & 35.27 & 8.24 & 18.17 & 24.02 & 3.48 & 3.75 & 49.42 \\
16 & 7.41 & 0.38 & 3.20 & 33.30 & 6.55 & 16.72 & 21.03 & 3.94 & 4.84 & 48.75 \\
17 & 5.92 & - & 2.74 & 38.41 & 8.55 & 16.33 & 20.40 & 3.03 & 4.62 & 44.38 \\
18 & 6.17 & - & 2.97 & 38.13 & 8.31 & 16.29 & 20.30 & 3.04 & 4.78 & 44.41 \\
19 & 6.43 & 0.67 & 4.07 & 29.80 & 7.51 & 16.30 & 23.14 & 4.43 & 3.14 & 47.01 \\
\hline
\end{tabular}

\subsection{Model fitting}

A SL was enzymatically synthesized via interesterification of hazelnut oil with CLA. A threefactor five-level CCD was employed for optimization of the reaction, the combinations of the three independent variables together with the responses are shown in Table 4. The regression coefficients and $\mathrm{P}$ values are given in Table 5 . The most significant effect was observed by substrate molar ratio $\left(\mathrm{S}_{\mathrm{r}}\right)$ followed by time $(\mathrm{t})$ and temperature $(\mathrm{T})$. The best-fitting quadratic model for CLA incorporation was estimated via multiple regression analysis and backward elimination. The first-order parameters of substrate molar ratio $\left(\mathrm{S}_{\mathrm{r}}\right)$ and time $(\mathrm{t})$ had positive effects on CLA incorporation, whereas the second-order parameter of time $\left(\mathrm{t}^{2}\right)$ had a negative effect on CLA incorporation. The first-order parameter of temperature (T), the second-order parameters of temperature $(T \times T)$ and substrate molar ratio $\left(\mathrm{S}_{r} \times \mathrm{S}_{\mathrm{r}}\right)$, were found to be nonsignificant for CLA incorporation. Moreover, the interaction terms of temperature and substrate molar ratio $\left(\mathrm{T} \times \mathrm{S}_{\mathrm{r}}\right)$, temperature and time $(\mathrm{T} \times \mathrm{t})$, and substrate molar ratio and time $\left(\mathrm{S}_{\mathrm{r}} \times \mathrm{t}\right)$ did not have a significant effect on CLA incorporation.

The model equation for CLA incorporation is described as follows:

CLA incorporation $(\%)=45.38+2.90 \mathrm{t}-2.88 \mathrm{t}^{2}+2.96 \mathrm{Sr}$

The ANOVA results for response surface reduced quadratic model (Table 6) revealed that the model was appropriate for the prediction. The model was significant $(\mathrm{P}<0.01)$ and showed no lack of fit $(\mathrm{P}=0.177)$. The $\mathrm{R}^{2}$ value of the model was 0.68 . 
Table 4. Central composite design arrangement with levels of factors and conjugated linoleic acid incorporation

\begin{tabular}{|c|c|c|c|c|}
\hline Trial No & $\begin{array}{l}\text { Substrate molar ratio } \\
\left(\mathrm{mol} \mathrm{mol}^{-1}\right)^{*}\end{array}$ & $\begin{array}{l}\text { Time } \\
\text { (h) }\end{array}$ & $\begin{array}{l}\text { Temperature } \\
\left({ }^{\circ} \mathrm{C}\right)\end{array}$ & $\begin{array}{c}\text { CLA incorporation } \\
(\%)\end{array}$ \\
\hline 1 & $1: 2$ & 6 & 59 & 41.00 \\
\hline 2 & $1: 3$ & 0 & 50 & 24.80 \\
\hline 3 & $1: 4$ & 24 & 41 & 47.78 \\
\hline 4 & $1: 2$ & 24 & 41 & 43.11 \\
\hline 5 & $1: 3$ & 15 & 65 & 42.71 \\
\hline 6 & $1: 4$ & 24 & 59 & 45.38 \\
\hline 7 & $1: 4.6$ & 15 & 50 & 45.51 \\
\hline 8 & $1: 3$ & 15 & 35 & 41.62 \\
\hline 9 & $1: 3$ & 15 & 50 & 44.47 \\
\hline 10 & $1: 4$ & 6 & 41 & 43.56 \\
\hline 11 & $1: 1.3$ & 15 & 50 & 36.07 \\
\hline 12 & $1: 3$ & 15 & 50 & 42.52 \\
\hline 13 & $1: 2$ & 24 & 59 & 40.87 \\
\hline 14 & $1: 2$ & 6 & 41 & 36.57 \\
\hline 15 & $1: 4$ & 6 & 59 & 49.42 \\
\hline 16 & $1: 3$ & 15 & 50 & 48.75 \\
\hline 17 & $1: 3$ & 15 & 50 & 44.38 \\
\hline 18 & $1: 3$ & 30 & 50 & 44.41 \\
\hline 19 & $1: 3$ & 15 & 50 & 47.01 \\
\hline
\end{tabular}

*: (mol of CLA)/(mol of hazelnut oil)

Table 5. Regression coefficients and $\mathrm{P}$ values

\begin{tabular}{lcc}
\hline Factor & Coefficent & P value \\
\hline Intercept & 45.38 & $0.000^{\mathrm{a}}$ \\
Substrate molar ratio (L) & 2.96 & $0.037^{\mathrm{b}}$ \\
Substrate molar ratio (Q) & -0.69 & 0.580 \\
Time (L) & 2.90 & $0.040^{\mathrm{b}}$ \\
Time (Q) & -2.88 & $0.041^{\mathrm{b}}$ \\
Temperature (L) & 0.55 & 0.662 \\
Temperature (Q) & -0.20 & 0.870 \\
Substrate molar ratio $\times$ time & -0.78 & 0.922 \\
Substrate molar ratio $\times$ temperature & 0.16 & 0.635 \\
Time $\times$ temperature & -1.87 & 0.268 \\
\hline
\end{tabular}

L; linear, Q; quadratic, ${ }^{a}$ statistically significant at $\mathrm{P}<0.01$, ${ }^{\mathrm{b}}$ statistically significant at $\mathrm{P}<0.05$. 
Table 6. ANOVA for response surface reduced quadratic model

\begin{tabular}{lccccc}
\hline & DF & MS & F value & P value & $\mathrm{R}^{2}$ \\
\hline Model & 3 & 114.34 & 7.66 & $0.0025^{\mathrm{a}}$ & 0.68 \\
Substrate molar ratio (L) & 1 & 114.71 & 7.69 & $0.0125^{\mathrm{a}}$ & \\
Time (L) & 1 & 119.99 & 8.04 & $0.0142^{\mathrm{a}}$ \\
Time (Q) & 1 & 108.31 & 7.26 & $0.0167^{\mathrm{a}}$ \\
Residual & 15 & 14.92 & & \\
Lack of fit & 11 & 17.92 & 2.68 & 0.1769 \\
Pure error & 4 & 6.69 & & & \\
Total & 18 & & & \\
\hline
\end{tabular}

DF: degree of freedom; MS: mean square; $\mathrm{R}^{2}$ : coefficient of determination; ${ }^{\text {a }}$ : statistically significant at $\mathrm{P}<0.05$

\subsection{Response surface plots}

The effect of the factor interactions on CLA incorporation could be assessed using contour plots. In Figure 3, contour plot shows the interaction between substrate molar ratio and temperature. CLA incorporation was shown to increase with an increment in substrate molar ratio. On the other hand, the incorporation of CLA was slightly influenced from the alterations in temperature. An increase in temperature enhances the enzyme activity until maximum reaction rate is achieved, and promotes the interaction between the substrate and enzyme (Senanayake \& Shahidi, 1999; Maduko et al., 2007; Bebarta et al., 2013). According to Kim and co-workers (2001), the incorporation of CLA into tricaprylin increased slightly with increasing temperature from 35 to $55^{\circ} \mathrm{C}$ (KIM et al., 2001). On the other hand, KANG and coworkers (2015) have reported a significant increase in CLA content when the temperature increased from $10^{\circ} \mathrm{C}$ to $20^{\circ} \mathrm{C}$. However, an increase in temperature from $20{ }^{\circ} \mathrm{C}$ to $30^{\circ} \mathrm{C}$ or $40^{\circ} \mathrm{C}$ did not have further effect on CLA content during the first $36 \mathrm{~h}$.

As substrate molar ratio and time increased up to certain extent $\left(3 \mathrm{~mol} \mathrm{~mol}^{-1}, 15 \mathrm{~h}\right)$, the incorporation of CLA increased (Fig. 2). However, the incorporation of CLA was found to be influenced slightly with further increase in those factors. The maximum response surface was reached at a substrate molar ratio above $3 \mathrm{~mol} \mathrm{~mol}^{-1}$ and reaction time above $15 \mathrm{~h}$. In KANG and co-workers' (2015) study, an increase in the substrate molar ratio from 1:0.5 to 1:1 caused a significant increase in CLA content after $24 \mathrm{~h}$. In VILLENEUVE and co-workers' (2007) study related to chemoenzymatic synthesis of structured TAGs with CLA, the optimum incorporation $(44.7 \%)$ and fastest kinetics were obtained from a donor mol ratio of 1:3 TAG/acyl.

The contour plot for interaction of time and temperature showed that an increase in time increased the incorporation of CLA to a certain extent (14 h). However, further increase in time had no significant effect on the incorporation of CLA. The maximum response surface was obtained at 14-26 h. The production of SL from safflower oil and CLA and the influence of reaction time on CLA incorporation were evaluated by LEE and co-workers (2004). The most incorporation of CLA was reported to occur within a short reaction time ( $<2$ hours). According to Mu and co-workers (1998), the incorporation of CLA steadily increased with an increment in time up to a certain extent, and longer reaction time (>15 h) was found to have no significant effect on the incorporation of CLA. 


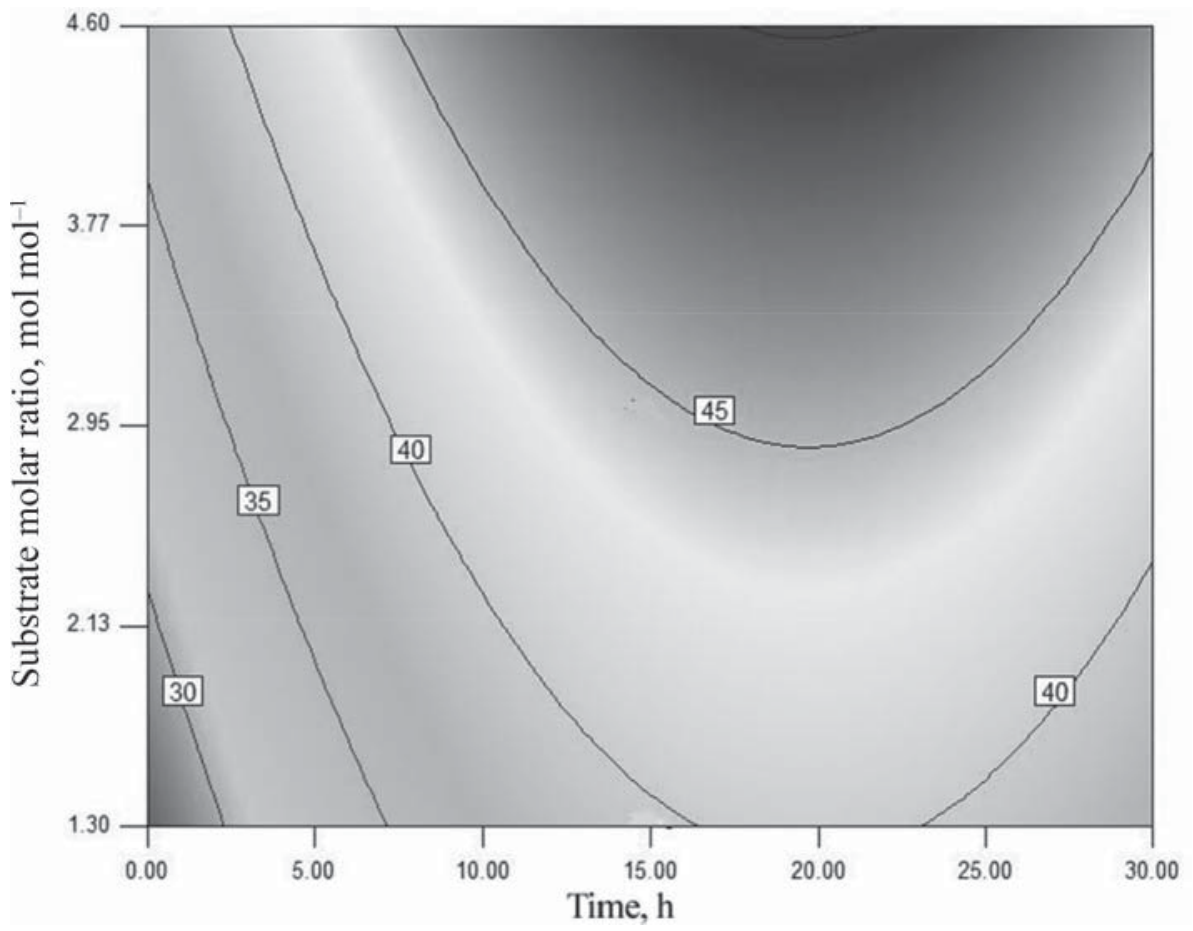

Fig. 3. Contour plots for the incorporation of CLA time-substrate molar ratio

\section{Conclusions}

In this study, the influences of substrate molar ratio, reaction temperature and time were investigated on the incorporation yield of CLA into hazelnut oil. In our study, it was found that the incorporation of CLA was insignificantly affected by the alteration of temperature at the working range. The incorporation of CLA was found to increase with increasing substrate molar ratio until maximum incorporation was achieved. Optimal incorporation conditions were determined as follows: reaction temperature, $59^{\circ} \mathrm{C}$; time, 6 hours; substrate molar ratio, 4. Under these optimal conditions, a maximum incorporation ratio of CLA into hazelnut oil of $49.42 \%$ was achieved.

This research was supported by Istanbul Technical University Scientific Research Projects Department.

\section{References}

Alim, M., Lee, J.-H., Акон, C., Choi, M.-S., Jeon, M.-S., Shin, J.-A. \& LeE, K.-T. (2008): Enzymatic transesterification of fractionated rice bran oil with conjugated linoleic acid: Optimization by response surface methodology. LWT - Food Sci. Technol., 41, 764-770.

Aloud, B.M., Raj, P., O’Hara, K., Shao, Z., Yu, L., Anderson, H.D. \& Netticadan, T. (2016): Conjugated linoleic acid prevents high glucose-induced hypertrophy and contractile dysfunction in adult rat cardiomyocytes. Nutr. Res., 36, 134-142. 
Bebarta, B., Jhansi, M., Kotasthane, P. \& Sunkireddy, Y.R. (2013): Medium chain and behenic acid incorporated structured lipids from sal, mango and kokum fats by lipase acidolysis. Food Chem., 136, 889-894.

CAN, A. \& OzCELIK, B. (2004): Enrichment of hazelnut oil by long chain $\omega-3$ PUFAs by lipase-catalyzed acidolysis: Optimization by RSM. J. Am. Oil Chem. Soc., 82, 27-32.

Fernandez-Avila, C., Arranz, E., Guri, A., Trujillo, A. \& Corredig, M. (2016): Vegetable protein isolate-stabilized emulsions for enhanced delivery of conjugated linoleic acid in Caco-2 cells. Food Hydrocolloids, 55, 144 154.

Hernández-Martí, E. \& Otero, C. (2008): Enzymatic re-esterification of lower glycerides from soybean oil with conjugated linoleic acid (CLA). J. Agr. Food Chem., 57, 701-708.

Jennings, B.H. \& Акон, C.C. (1999): Enzymatic modification of triacylglycerols of high eicosapentaenoic and docosahexaenoic acids content to produce structured lipids. J. Am. Oil Chem. Soc., 76, 1133-1137.

Kahveci, D., Can, A. \& OzceliK, B. (2009): Production of lipase-catalyzed structured lipid from olive oil with omega-3 polyunsaturated fatty acids. Food Sci. Biotechnol.,18, 79-83.

Kang, I., BANG, H.-J., Kiм, I.-H., ChoI, H.-D. \& Kiм, B.H. (2015): Synthesis of trans-10, cis-12 conjugated linoleic acid-enriched triacylglycerols via two-step lipase-catalyzed esterification. LWT - Food Sci. Technol., 62, $249-256$.

Kelley, N.S., HubBard, N.E. \& ERickson, K.L. (2007): Conjugated linoleic acid isomers and cancer. J. Nutr., 137, 2599-2607.

Kim, I.-H., Yoon, C.-S., Сно, S.-H., LeE, K.-W., Chung, S.-H. \& TAE, B.-S. (2001): Lipase-catalyzed incorporation of conjugated linoleic acid into tricaprylin. J. Am. Oil Chem. Soc., 78, 547-551.

Leão, B., Rocha-Frigoni, N., Cabral, E., Coelho, M., Ferreira, C., Eberlin, M., Accorsi, M., Nogueira, É. \& Mingoti, G. (2015): Improved embryonic cryosurvival observed after in vitro supplementation with conjugated linoleic acid is related to changes in the membrane lipid profile. Theriogenology, 84, 127-136.

Lee, J.-H., Shin, J.-A., Lee, J.-H. \& Lee, K.-T. (2004): Production of lipase-catalyzed structured lipids from safflower oil with conjugated linoleic acid and oxidation studies with rosemary extracts. Food Res. Int., 37, 967-974.

Lee, J.H., Lee, K.-T., Aкон, C.C., Chung, S.K. \& Kim, M.R. (2006): Antioxidant evaluation and oxidative stability of structured lipids from extravirgin olive oil and conjugated linoleic acid. J. Agr. Food Chem., 54, 54165421.

Maduko, С., Акон, С. \& PARK, Y. (2007): Enzymatic production of infant milk fat analogs containing palmitic acid: optimization of reactions by response surface methodology. J. Dairy Sci., 90, 2147-2154.

McLeod, R.S., LeBlanc, A.M., Langille, M.A., Mitchell, P.L. \& Currie, D.L. (2004): Conjugated linoleic acids, atherosclerosis, and hepatic very-low-density lipoprotein metabolism. Am. J. Clin. Nutr., 79, 1169S-1174S.

Mu, H., Xu, X. \& Høy, C.-E. (1998): Production of specific-structured triacylglycerols by lipase-catalyzed interesterification in a laboratory-scale continuous reactor. J. Am. Oil Chem. Soc., 75, 1187-1193.

NASRABADI, M.N. \& Goli, S.A.H. (2016): Stability assessment of conjugated linoleic acid (CLA) oil-in-water beverage emulsion formulated with acacia and xanthan gums. Food Chem., 199, 258-264.

Ryder, J., Portocarrero, C., Song, X., Cui, L., Yu, M., Combatsiaris, T., ... \& Houseknecht, K.L. (2001): Isomerspecific antidiabetic properties of conjugated linoleic acid. Diabetes, 50, 1149-1157.

Salamon, R., Vargáné-Visi, É., András, C.D., Csapóné Kiss, Z. \& Csapó, J. (2015): Synthetic methods to obtain conjugated linoleic acids (CLAs) by catalysis - A review. Acta Alimentaria, 44, 229-234.

SenAnayAKe, S.N. \& Shahidi, F. (1999): Enzymatic incorporation of docosahexaenoic acid into borage oil. J. Am. Oil Chem. Soc., 76, 1009-1015.

Villeneuve, P., Barouh, N., Baréa, B., Piombo, G., Figueroa-Espinoza, M.-C., Turon, F., Pina, M. \& Lago, R. (2007): Chemoenzymatic synthesis of structured triacylglycerols with conjugated linoleic acids (CLA) in central position. Food Chem., 100, 1443-1452.

Vu, P.-L., Park, R.-K., Lee, Y.-J., Kim, Y.-M., Nam, H.-Y., LeE, J.-H., АкоH, C.C. \& LeE, K.-T. (2007): Two-step production of oil enriched in conjugated linoleic acids and diacylglycerol. J. Am. Oil Chem. Soc., 84, 123-128. 